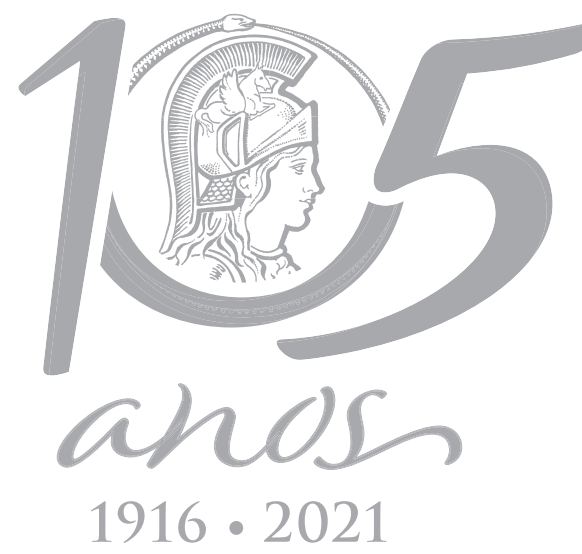

\title{
Weight/carapace length relationship and condition factor of the roughneck shrimp, Rimapenaeus constrictus (Stimpson, 1874), on the southeastern Brazilian coast
}

\author{
ALEXANDRE R. DA SILVA, ANA ELISA B. LOPES, RAPHAEL C. GRABOWSKI \& \\ ANTONIO L. CASTILHO
}

Abstract: Rimapenaeus constrictus is a penaeid shrimp widely distributed in the Western Atlantic, frequently captured as bycatch in trawling activities. Here we describe the weight vs. carapace length relationship and the condition factor of the species. Shrimps were sampled in the Ubatuba region, northern littoral of São Paulo State, monthly. We analyzed 4,952 individuals (1,371 males and 3,581 females). We measured the individuals' weight and carapace length, and the condition factor (CF) was calculated for both sexes. Females had a heavier body when compared to males, probably due to their greater maximum body size achieved. Both sexes presented a negative allometric growth in weight, probably due to their reproductive pattern and activities. We found similar mean CF values for males and females. From temporal analysis, the highest CF values for females were observed during the seasons with lower water temperatures. Such a situation may happen because females' CF tend to be influenced by a greater food availability in the environment, induced by the intrusion of the South Atlantic Central Water during the spring and early summer in the Ubatuba. The information presented here could be used as subside in protection actions and management of bycatch species.

Key words: Allometry, degree of fattening, Penaeidae, wellness.

\section{INTRODUCTION}

Rimapenaeus constrictus (Stimpson, 1874), also known as 'roughneck shrimp' exhibits a wide geographical distribution, with occurrences recorded from Nova Scotia (Canada, $44^{\circ} \mathrm{N}$ ) through Santa Catarina (Brazil, 26 S) (Costa et al. 2003). Unfortunately, their broad geographical range may result in an equally high influence from the shrimp-fishing activities. This species is among the most often accidentally caught by non-selective fishing gear during trawling activities, mainly in the northern coast of São Paulo State (Brazil) (Keunecke et al. 2007, Mantelatto et al. 2016), and due to its small size, it is not commercially exploited (Lopes et al. 2017). In this sense, even though $R$. constrictus does not represent an expressive economic resource, as it is part of the bycatch fauna, and are an important species in nutrient cycling having an important ecological role in marine food webs (Pérez-Farfante \& Kensley 1997, Costa \& Fransozo 2004a, b, Keunecke et al. 2007).

According to Gould (1966), the relative growth occurs when organisms respond to environmental variations or physiological needs through differences in growth rates of particular parts of the body. This process is frequently studied through morphometric relationships 
between different parts of the body, or between length and weight, or length and volume (adjusted by the power function $y=a . x^{b}$ ) (Gould 1966). The growth in weight may differ according to each maturation phase, in populations from different localities and between sexes (Hartnoll 1982). The weight/carapace length relationship provides important information about the population's biomass, acts as an indicative of fatness, and demonstrates its environmental adaptive capability (Santos 1978, Froese 2006). However, knowledge about the fattening aspects of $R$. constrictus remains scarce.

Even being substantially captured by the trawling fleet, only a few studies have been undertaken to elucidate the basic biology of this species. Along the Brazilian coast, specifically in the northern coast of São Paulo State (Brazil) several studies were conducted focusing on its distribution, reproductive ecology and growth (Costa \& Fransozo 2004a, b, Hiroki et al. 2011, Lopes et al. 2017). In the southern littoral of São Paulo State, Garcia et al. (2016) addressed its reproductive dynamics and growth. In addition to the studies conducted on the Brazilian coast, Bauer \& Lin (1994) evaluated the reproductive and recruitment periods of the congeneric species, Rimapenaeus similis (Smith, 1885) and $R$. constrictus, in the Gulf of Mexico.

It is important to point out that, to the date, there are no available studies in the literature, concerning neither the weight vs carapace length relationship nor the condition factor of $R$. constrictus, what makes the present study the first using this tool for the roughneck shrimp. It is necessary to strengthen the knowledge about different aspects of its biology to provide for the maintenance of an effective conservation plan, especially when considering that the current knowledge is insufficient to take scientifically based decisions, such as the sustainable use measurements for marine shrimp fishing (Dias Neto 2011).

Facing this scenario, we here described the condition factor and the relationship between weight and carapace length for $R$. constrictus, within 2 years in Ubatuba, northern littoral of São Paulo State.

\section{MATERIALS AND METHODS}

\section{Sampling}

Sampling was carried out monthly from Jan/1998 through Dec/1999 along the northern coast of São Paulo State, in the Ubatuba region $\left(23^{\circ} 29^{\prime} 06^{\prime \prime} \mathrm{S}\right.$, $45^{\circ} 05^{\prime} 00^{\prime \prime} \mathrm{W}$ ). Samples were obtained during the day using a shrimp-fishing boat outfitted with double-rig nets (mesh size: $20 \mathrm{~mm}$ knot-toknot in the body and $15 \mathrm{~mm}$ in the cod end). The average temperature was measured with the Eureka multiparameter probe. Individuals were sorted to sex, according to the morphology of the first pleopod (males) or the sternum (females) (Costa et al. 2003). Shrimps were then measured with an analog caliper (0.05 $\mathrm{mm}$ precision) to their carapace length ( $\mathrm{CL}$, a standard body measurement that corresponds to the linear distance from the post-orbital angle and the posterior margin of the carapace). Shrimps were dried in an oven $\left(60^{\circ} \mathrm{C}\right.$ for $\left.48 \mathrm{~h}\right)$ to obtain the dry weight (WE), which was then determined by an electronic digital balance (0.0001 g precision). The dry weight was used because the animals were fixed in alcohol solution (70\%) and then transported to the laboratory, and because alcohol dehydrates the material, we employed dry weight to standardize the weight measures. The normality of the CL and WE were tested, and the proper statistic test were used to compare males and females. 


\section{Condition factor and weight/carapace length relationship}

Before the analysis the biometric data (Weight and Carapace Length) were log-transformed to obtain normality to attend to statistical premises. The WE/CL relationship was estimated using the logarithmic form InWE = Ina + blnCL, considering WE as the dependent variable and $C L$ as the independent variable (Froese 2006). The 'b' allometric constant value was tested using the Student's t-test $(p=0.05)$ (Zar 2010). The value of 'b' represents the type of growth, indicating an isometry ( $b=3$, weight and carapace length grow in equal proportions), positive allometry $(b>3$, weight increases more in than carapace length) and negative allometry ( $b<3$, carapace length increases more than to weight) (Froese 2006).

The modified power function $a=W E / C L^{b}$ was used to estimate the condition factor ' $a$ ', individually and for each sex, whereas the WE/ $\mathrm{CL}$ relation was used to determine the constant 'b' of all individuals (Okon \& Sikoki 2014). The normality of the condition factor values obtained were verified using the Shapiro-Wilk test, and posteriorly compared using the Wilcoxon test ( $p$ $=0.05)($ Zar 2010).

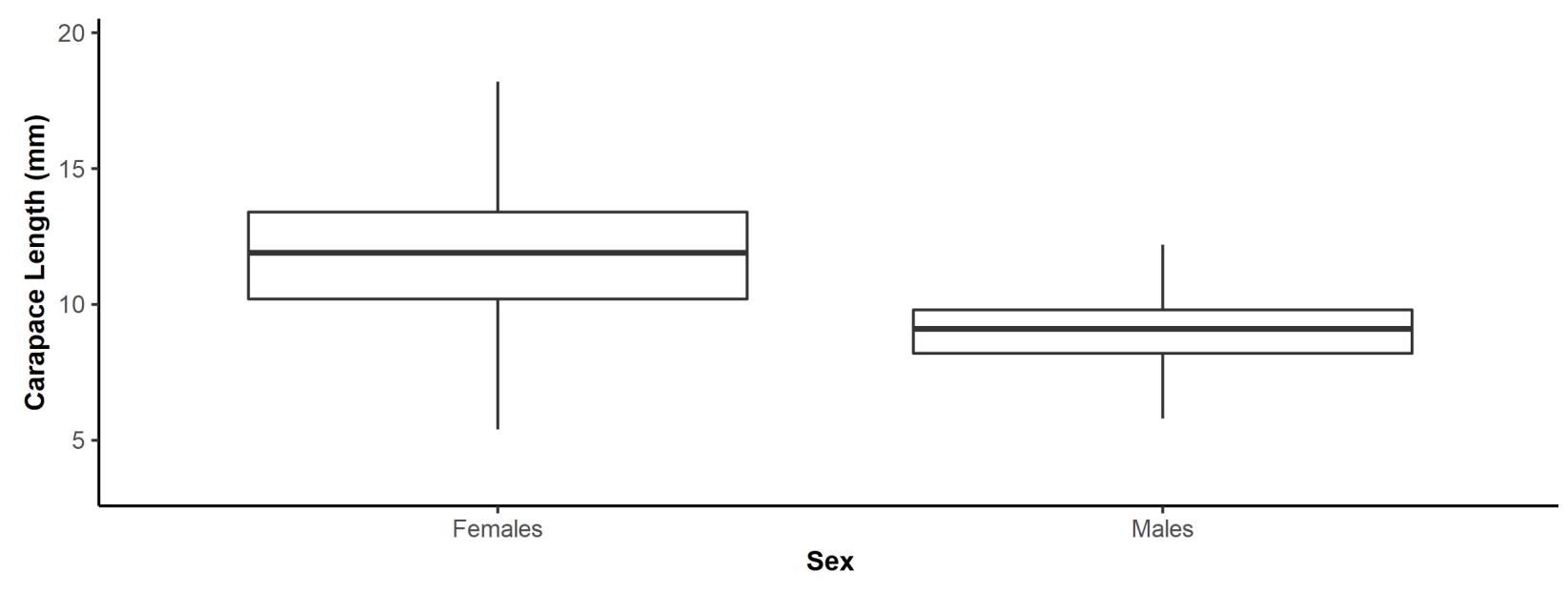

The data were grouped into seasons (summer: January to March, autumn: from April to June, winter: July to September, spring: October to December) so the data of condition factor and temperature could be better visualized. To identify differences in the condition factor between years (1998 x 1999), for each sex separately, we used the Wilcoxon test ( $p=0.05$ ).

\section{RESULTS}

During this study, 4,952 individuals of $R$. constrictus were analyzed (1,371 males and 3,581 females). The $\mathrm{CL}$ ranged from 4.1 to $15.7 \mathrm{~mm}$ in males and from 3.4 to $19.7 \mathrm{~mm}$ in females (Figure 1). The median $\mathrm{CL}$ registered for males was significantly different from the median $\mathrm{CL}$ observed for females (Wilcoxon, $W=688057, p<$ 0.001). The WE varied from 0.05 to $2.8 \mathrm{~g}$ in males, and from 0.05 to $4.17 \mathrm{~g}$ in females (Figure 2). The median WE obtained for males was statistically different from the median obtained for females (Wilcoxon, $W=784686 p<0.001$ ).

The WE/CL relationship presented a negative allometric growth weight $(b<3)$ for both sexes, the equations and values can be seen in Figure 3 and Table I.

Figure 1. Rimapenaeus constrictus (Stimpson, 1874). Boxplot of Carapace Length (CL) for both sexes. Line inside the box indicates median, box indicate first and third quartiles and whiskers indicates minimum and maximum. 
The condition factor (CF) presented a nonnormal distribution for both males ( $W=0.88$, $p<0.05)$ and females ( $W=0.85, p<0.05)$, with very similar values for both sexes (Figure 4 ). The median CF analyzed for males showed no significant difference from that one observed for females (Wilcoxon, $W=2430332, p=0.58$ ). The highest CF values observed for females were during the winter and spring/98, and spring/99. The males median values of CF did not differ between the years (Wilcoxon, $\mathrm{W}=228196, \mathrm{p}$ $=0.2$ ), however, the females median values were significant different between the years (Wilcoxon, $W=1539058, p=0.04$ ) (Figure 5).

\section{DISCUSSION}

Penaeid species tend to exhibit differences in growth rate between sexes (Gab-Alla et al. 1990). According to Eberhard (2009), different selective pressures over both females and males may induce the commonly observed sexual dimorphism in body size. In this sense, such morphological difference is nothing but a result of the different energetic output and reproductive roles between sexes. Individuals of $R$. constrictus were widely reported displaying such a sexual dimorphism, since females usually reach greater sizes than males, as observed in our results (Costa \& Fransozo 2004a, Garcia et al. 2016, Lopes et al. 2017). Some authors suggest that this difference in $C L$ might be related to their reproductive aspects (Gab-Alla et al. 1990, Costa \& Fransozo 2004a). According to Garcia et al. (2016), males of $R$. constrictus have a higher growth rate $(k)$ than females with a shorter lifespan, therefore, males could reach maturity sooner than females and would be able to copulate with larger females and since males have a short lifespan they could disappear from population while the females remain and keep growing reaching larger sizes.

According to Hartnoll (1982), the weight gain pattern is ontogenetically determined, varying between sexes in the same species. For Rio de Janeiro region, were found that females had negative allometry growth for fattening and isometric growth for males (Oliveira-Souza \& Lavrado 2017), the "b" values found by the authors are close to what found in our study, especially for females. We propose that uncountable factors could be related to the higher WE observed in females in our study. We suggest that the higher $\mathrm{CL}$ observed for females probably was the main

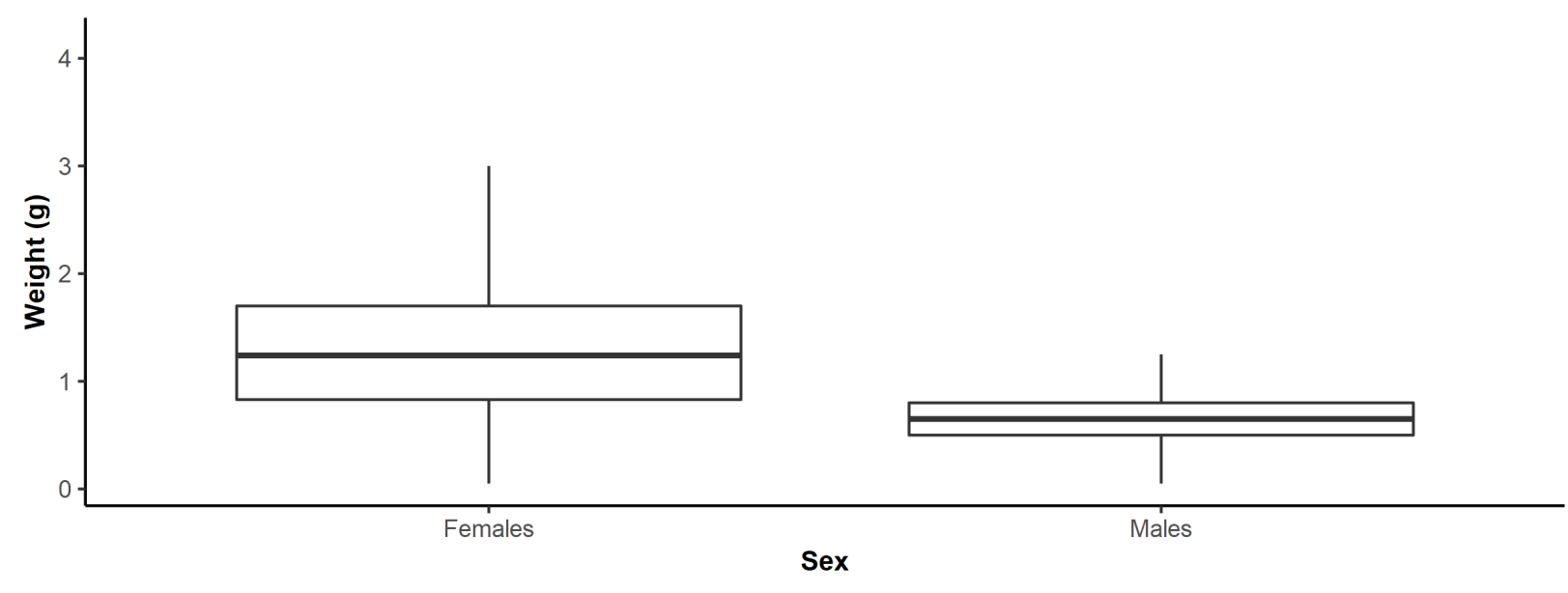

Figure 2. Rimapenaeus constrictus (Stimpson, 1874). Boxplot of Weight (WE) for both sexes. Line inside the box indicates median, box indicate first and third quartiles and whiskers indicates minimum and maximum. 
reason that led to a heavier body weight since they are a collinear data (see $r^{2}$ values at Figure 1 and Table I), although we do not discard the influence of the other factors. According to Lopes et al. (2017), the type of the sediment in the Ubatuba region (same region and period as the present study) are characterized by very coarse, coarse and medium sand which favors both a higher retention of organic matter (a food resource) and the species' burrowing behavior (Mantelatto \& Fransozo 1999). Besides, females tend to feed for longer periods than males to supply the nutrients need during their gonadal maturation period (Kevrekidis \& Thessalou-Legaki 2006). In this way, we also propose that the longer feeding time can induce an increased WE in females. Besides that, the female tendency of higher energetic investment in the development of the gonad could be an additional reason for them to present a heavier body weight than males, mainly during the reproductive period (Hines 1982, Hartnoll 1985, Lopez-Greco \& Rodriguez 1999, Zara et al. 2013).

The similarity in the CF values between the sexes may demonstrate that even though females presented a higher body weight, the fattening rate tends to be similar for both sexes. This pattern of similar CF between sexes were also seen for other peneid shrimps such as
Penaeus semisulcatus De Haan, 1844 (Thomas 1975) and Penaeus monodon Fabricius, 1798 (Gopalakrishnan et al. 2014). As pointed out by Santos-Filho et al. (2016), this similarity may indicate that the CF does not depend on the largest size reached by each sex, as observed in our results. Thus, we strongly suggest that even though there is some similarity in the CF values between the sexes, females are heavier because they reach larger body sizes.

The southeastern Brazilian continental shelf is influenced by water masses such as the South Atlantic Central Water (SACW), which is responsible for the decreasing in water temperature and salinity during the spring and early summer (Castro-Filho et al. 1987). In our study, we detected this decrease in water temperature during spring $98 / 99$, induced by the intrusion of the SACW, which has already been previously detected by Costa \& Fransozo (2004a). According to Vega-Pérez (1993), the SACW approaching increases the phytoplankton production, consequently, increasing the water $\alpha$-chlorophyll concentration, confirming the tendency for water enrichment along the continental shelf during summer (Castro-Filho et al. 1987). The major peaks of females' CF values were observed during the seasons with low water temperature. Although Branco et al. (1992)
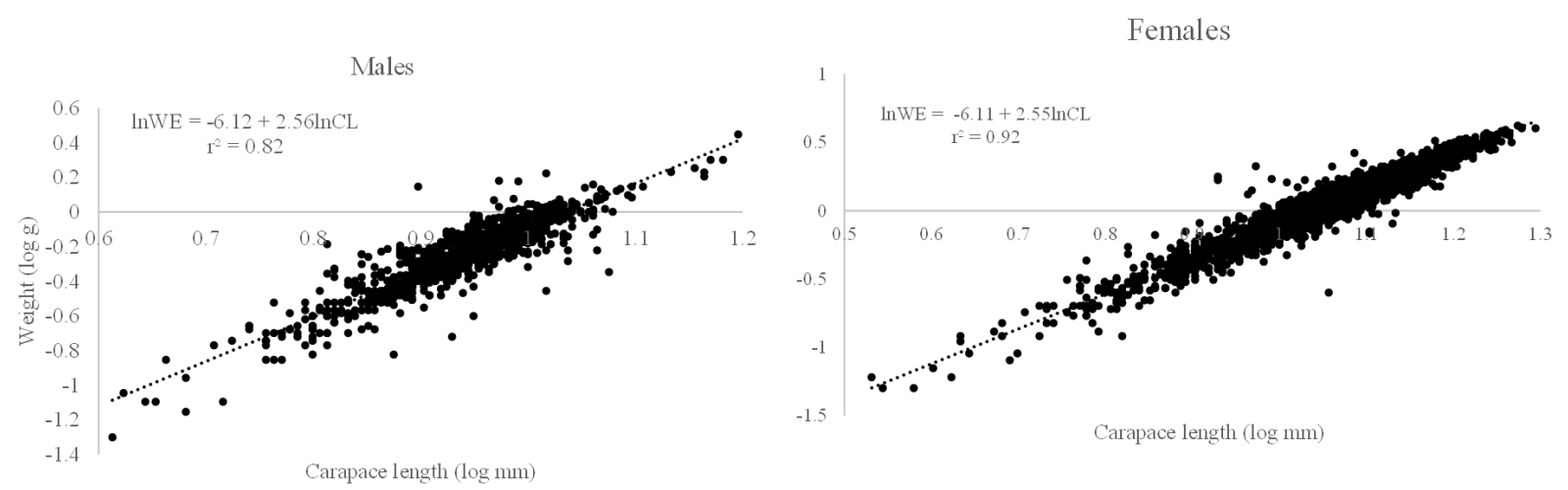

Figure 3. Rimapenaeus constrictus (Stimpson, 1874). Scatter plot of weight (WE) and carapace length (CL) for males and females sampled from January 1998 through December 1999 in the northern São Paulo State littoral, Brazil. 
stated that the gonadal development presents a higher influence over the CF when compared to the food availability, the CF has been determined as an index of both growth and intensity of feeding (Branco et al. 1992, Froese 2006) and, if so, it can be influenced by the availability of food in the environment (Pinheiro \& Fiscarelli 2009). Therefore, we propose that the amount of nutrients available during the intrusion of SACW might also have influenced the peaks of higher females' degree of fattening, even though we do not discard the possibility of other influences.

The negative allometry registered for both males and females indicates that individuals displayed a higher increase in $\mathrm{CL}$ (size) than in WE. Because R. constrictus exhibits a continuous reproduction throughout the year in the same region as addressed in our study (Costa \& Fransozo 2004a), we may infer that individuals were constantly investing energy in both growth and gonadal development. However, we suggest that during the reproductive activities, when males copulate (releasing their spermatophores) and females spawn, part of their weight, which had once been invested in gonadal development, is lost, since it is converted into their offspring (Dall et al. 1990). If so, the constant weight loss in each reproductive cycle and the weight gain (provided by the continuous gonadal investment) at the end of it makes their weight to be frequently oscillating. It probably explains the individual's reason to grow more in size than in weight, because growth would occur continuously, without losses, whereas weight would be susceptible to such variations during each reproductive event (Dall et al. 1990). Moreover, the "b" constant determined in our results was within the common values previously obtained for other aquatic organisms, including other decapod crustaceans (between 2 and 4) (Hartnoll 1982).

The $W E / C L$ relationship and patterns of condition factor provide important information to increase the knowledge of the species' biology, especially considering the lack of studies addressing $R$. constrictus. Such information may be helpful to protect this widely captured bycatch species, and therefore, we encourage the development of more detailed laboratory studies to determine the additional factors that may influence the $W E / C L$ relationship and the patterns on the condition factor.

Table I. Rimapenaeus constrictus (Stimpson, 1874). Results of the regression analyses for individuals sampled from January 1998 through December 1999 in the Ubatuba region, northern São Paulo State littoral, Brazil.

\begin{tabular}{|c|c|c|c|c|c|}
\hline Sex & $\mathbf{n}$ & $\begin{array}{c}\text { Linearized Equation } \\
\text { Iny }=\text { Ina } \mathbf{b} \cdot \mathbf{l n} \mathbf{x}\end{array}$ & $\mathbf{r}^{\mathbf{2}}$ & $\mathbf{t}\left(\mathbf{H}_{\mathbf{0}}: \mathbf{b}=\mathbf{3}\right)$ & Allom. \\
\hline$M$ & 1371 & $\operatorname{lnWE}=-6.12+2.56 \operatorname{lnCL}$ & 0.82 & 80.36 & - \\
\hline$F$ & 3581 & $\operatorname{LnWE}=-6.11+2.55 \operatorname{lnCL}$ & 0.92 & 216.7 & - \\
\hline
\end{tabular}




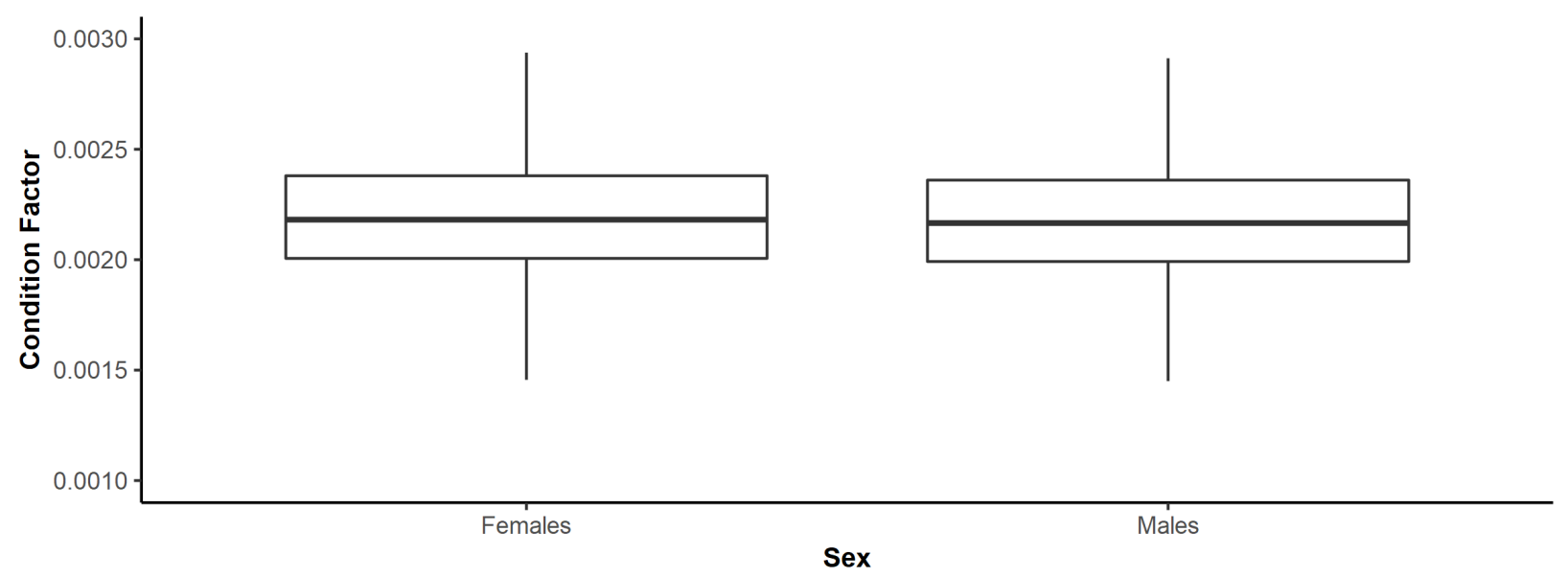

Figure 4. Rimapenaeus constrictus (Stimpson, 1874). Boxplot of Condition Factor for both sexes. Line inside the box indicates median, box indicate first and third quartiles and whiskers indicates minimum and maximum.

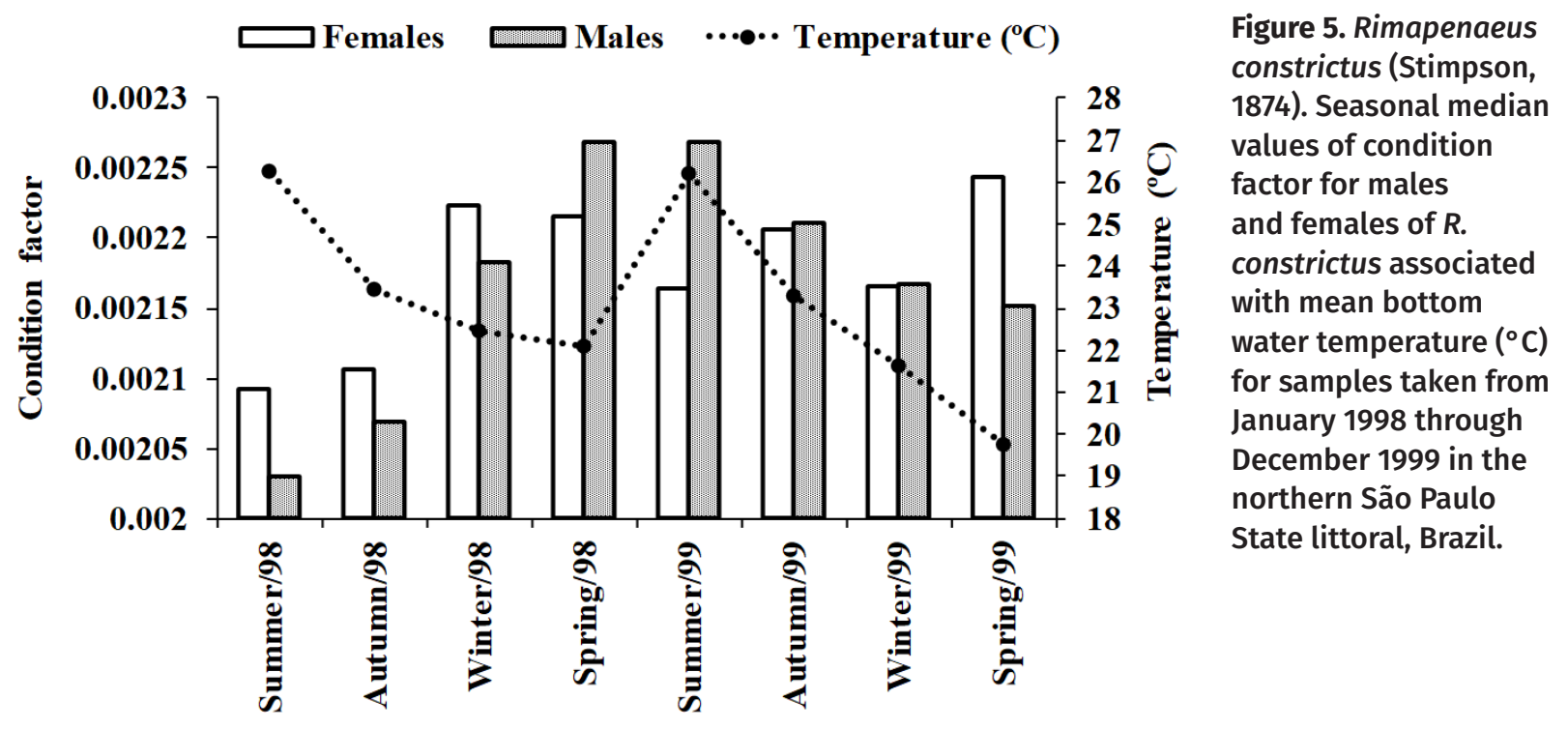

\section{Acknowledgments}

This study was financed in part by the Coordenacão de Aperfeiçoamento de Pessoal de Nivel Superior - Brazil (CAPES) - Finance Code 001. We thank many colleagues from the NEBECC group who helped with sampling and laboratory analyses; and the Instituto Brasileiro do Meio Ambiente e dos Recursos Naturais Renováveis (IBAMA) for granting permission to collect the shrimps. This work was supported by the Fundação de Amparo à Pesquisa do Estado de São Paulo (FAPESP) (Biota \# 98/07090-3, \# 2010/50188-8; Scholarships \# 97/12106-8, \# 07/567335, \# 2015/13639-5); Coordenação de Aperfeiçoamento de Pessoal de Nivel Superior - Ciências do Mar (CAPES - CIMAR) (\# 23038.004310/2014-85) and Conselho
Nacional de Desenvolvimento Científico e Tecnológico (CNPq) (Research Scholarships PQ 305919/2014-8; PQ 308653/2014-9).

\section{REFERENCES}

BAUER RT \& LIN J. 1994. Temporal patterns of reproduction and recruitment in populations of the penaeid shrimps Trachypenaeus similis (Smith) and T. constrictus (Stimpson) (Crustacea: Decapoda) from the Northcentral Gulf of Mexico. J Exp Mar Bio Ecol 182(2): 205-222.

BRANCO JO, LUNARDON MJ, AVILA MG \& MIGUEZ CFM. 1992. Interação entre fator de condição e índice 
gonadossomático como indicadores do período de desova em Callinectes danae Smith (Crustacea, Portunidae) da Lagoa da Conceição, Florianópolis, Santa Catarina, Brasil. Rev Bras Zool 9(3/4): 175-180.

CASTRO-FILHO BM, MIRANDA LB \& MIYAO SY. 1987. Condições hidrográficas na plataforma continental ao largo de Ubatuba: variações sazonais e em média escala. Bolm Inst Oceanogr 35: 135-151.

COSTA RC \& FRANSOZO A. 2004a. Reproductive biology of the shrimp Rimapenaeus constrictus (Decapoda, Penaeidae) in the Ubatuba region of Brazil. J Crust Biol 24(2): 274-281.

COSTA RC \& FRANSOZO A. 2004b. Abundance and ecologic distribution of the shrimp Rimapenaeus constrictus (Crustacea: Penaeidae) on the northern coast of São Paulo State, Brazil. J Nat Hist 38(7): 901-912.

COSTA RC, FRANSOZO A, MELO GAS \& FREIRE FAM. 2003. Chave ilustrada para identificação dos camarões Dendrobranchiata do litoral norte do estado de São Paulo, Brasil. Biota Neotrop 3: 1-12.

DALL WHBJ, HILL BJ, ROTHLISBERG PC \& SHARPLES DJ. 1990. The biology of the Penaeidae. In: Blaxter JHS and Southward AJ (Eds). Advances in Marine Biology. San Diego, Academic Press, $489 \mathrm{p}$.

DIAS NETO J. 2011. Proposta de plano nacional de gestão para o uso sustentável de camarões marinhos do Brasil. Brasília: Instituto Brasileiro do Meio Ambiente e dos Recursos Naturais Renováveis e Ministério do Meio Ambiente. IBAMA 59(1): 242 p.

EBERHARD WG. 2009. Static allometry and animal genitalia. Evolution 63(1): 48-66.

FROESE R. 2006. Cube law, condition factor and weightlength relationships: history, meta-analysis and recommendations. J Appl Icthyol 22(4): 241-253.

GAB-ALLA AAFA, HARTNOLL RG, GHOBASHY AF \& MOHAMMED SZ. 1990. Biology of penaeid prawns in the Suez Canal lakes. Mar Biol 107: 417-426.

GARCIA JR, WOLF MR, COSTA RC \& CASTILHO AL. 2016. Growth and reproduction of the shrimp Rimapenaeus constrictus (Decapoda: Penaeidae) from the southeastern coast of Brazil. Reg Stud Mar Sci 6: 1-9.

GOPALAKRISHNAN A, RAIJKUMAN M, RAHMAN MM, SUN J, ANTONY PJ, VENMATHI MARAN BA \& TRILLES JP. 2014. Length-weight relationship and condition factor of wild, grow-out and 'loose-shell affected' giant tiger shrimp, Penaeus monodon (Fabricius, 1798) (Decapoda: Penaeidae). J Appl Ichthyol 30(1): 251-253.
GOULD SJ. 1966. Allometry and size in ontogeny and phylogeny. Biol Rev 41(4): 587-640.

HARTNOLL RG. 1982. Growth. In: Abele LG (Ed). The biology of Crustacea. Vol 2. New York: Academic Press, 111-196.

HARTNOLL RG. 1985. Growth, sexual maturity and reproductive output. In: Wenner AM (Ed). Factors in adult growth. Rotterdam: A. A. Balkema, p. 101-129.

HINES AH. 1982. Allometric constraints and variables of reproductive effort in brachyuran crabs. Mar Biol 69: 309-320.

HIROKI KAN, FRANSOZO A, COSTA RC, CASTILHO AL, SHIMIZU RM, ALMEIDA AC \& FURLAN M. 2011. Bathymetric distribution of the shrimp Rimapenaeus constrictus (Stimpson, 1874) (Decapoda, Penaeidae) in two locations off the southeastern Brazilian coast. Mar Biol Res 7(2): 176-185.

KEUNECKE KA, VIANNA M, FONSECA DB \& D'INCAO F. 2007. The pink-shrimp trawling bycatch in the northern coast of São Paulo, Brazil, with emphasis on crustaceans. Nauplius 15(2): 49-55.

KEVREKIDIS K \& THESSALOU-LEGAKI M. 2006. Catch rates, size structure and sex ratio of Melicertus kerathurus (Decapoda: Penaeidae) from an Aegean Sea trawl fishery. Fish Res 80: 270-279.

LOPES AEB, GRABOWSKI RC, GARCIA JR, FRANSOZO A, COSTA RC, HIROKI KA \& CASTILHO AL. 2017. Population dynamics of Rimapenaeus constrictus (Stimpson, 1874) (Penaeoidea) on the southeastern Brazilian coast: implications for shrimp fishing management from a 5-year study on a bycatch species. An Acad Bras Cienc 89: 1013-1025.

LÓPEZ-GRECO LS \& RODRÍGUEZ EM. 1999. Annual reproduction and growth of adult crabs Chasmagnathus granulata (Crustacea, Brachyura, Grapsidae). Cah Biol Mar 40: 155-164.

MANTELATTO FL, BERNARDO CH, SILVA TE, BERNARDES VP, COBO VJ \& FRANSOZO A. 2016. Composição e distribuição de crustáceos decápodes associados à pesca do camarãosete-barbas Xiphopenaeus kroyeri (Heller, 1862) no litoral norte do estado de São Paulo. Bolm Inst Pesc 42(2): 307-326.

MANTELATTO FLM \& FRANSOZO A. 1999. Characterization of the physical and chemical parameters of Ubatuba Bay, Northern coast of Sao Paulo State, Brazil. Rev Bras Biol 59: 23-31.

OKON EA \& SIKOKI FD. 2014. Length-Weight Relationship and Condition Factor of the West African Fiddler Crab (Uca tangeri) in MboRiver, Akwalbom State, Nigeria. J Nat Sci Res 4: 33-42. 
OLIVEIRA-SOUZA W \& LAVRADO HP. 2017. Population structure and temporal variation of the roughneck shrimp Rimapenaeus constrictus (Decapoda: Penaeoidea) in a coastal bay of the Southwestern Atlantic. Mar Biol Res 13(10): 1073-1083.

PÉREZ-FARFAnTE I \& KEnSLEY B. 1997. Penaeoid and Sergestoid shrimps and prawns of the World. Keys and diagnoses for the families and genera. Paris, Éditions du Muséum National d Histoire Naturalle, 233 p.

PINHEIRO MAA \& FISCARELLI AG. 2009. Length-weight relationship and condition factor of the Mengrove Crab Ucides cordatus (Linnaeus, 1763) (Crustacea, Brachyura, Ucididae). Braz Arch Biol Technol 52(2): 397-406.

SANTOS EP. 1978. Dinâmica de populações aplicada à pesca e piscicultura. São Paulo: Hucitec, EDUSP, 129 p.

SANTOS FILHO LGA, SANTOS SGAV, GÓES JM \& FERNANDES-GÓES LC. 2016. Temporal analysis of the weight/carapace width relationship and the condition factor in Uca mordax (Smith, 1870) (Crustacea, Decapoda, Ocypodidae) in the Igaraçu River, Parnaíba, PI, Brazil. Biotemas 29(1): 47-53.

THOMAS MM. 1975. Age and growth, length-weight relationship and relative condition factor of Penaeus semisulcatus de Haan. Indian J Fish 22(1\&2): 133-142.

VEGA-PÉREZ LA. 1993. Estudo do zooplâncton da região de Ubatuba, Estado de São Paulo. Bolm Inst Oceanogr 10: 65-84.

ZAR JH. 2010. Bioestatistical Analysis. New Jersey, Pearson Prentice-Hall, $944 \mathrm{p}$.

ZARA FJ, GAETA HH, COSTA TM, TOYAMA MH \& CAETANO FH. 2013. The ovarian cycle histochemistry and its relationship with hepatopancreas weight in the blue crab Callinectes danae (Crustacea: Portunidae). Acta Zool 94(2):134-146.

\section{How to cite}

SILVA AR, LOPES AEB, GRABOWSKI RC \& CASTILHO AL. 2021. Weight/ carapace length relationship and condition factor of the roughneck shrimp, Rimapenaeus constrictus (Stimpson, 1874), on the southeastern Brazilian coast. An Acad Bras Cienc 93: e20190570. DOI 10.1590/00013765202120190570 .
Manuscript received on May 17, 2019;

accepted for publication on August 15, 2019

\section{ALEXANDRE R. DA SILVA}

https://orcid.org/0000-0001-8921-8767

\section{ANA ELISA B. LOPES ${ }^{2}$}

https://orcid.org/0000-0002-9513-0902

\section{RAPHAEL C. GRABOWSKI ${ }^{2}$}

https://orcid.org/0000-0001-9414-8310

\section{ANTONIO L. CASTILHO}

https://orcid.org/0000-0003-0001-9054

'Universidade Estadual do Norte do Paraná/ UENP, Campus Cornélio Procópio, Rua Portugal 340, 86300-000 Cornélio Procópio, PR, Brazil

${ }^{2}$ Universidade Estadual Paulista, Instituto de Biociências de Botucatu, Departamento de Bioestatística, Biologia Vegetal, Parasitologia e Zoologia, Rua Prof. Dr. Antônio Celso Wagner Zanin 250, Distrito de Rubião Júnior, 18618-689 Botucatu, SP, Brazil

\section{Correspondence to: Alexandre Ribeiro da Silva}

E-mail: alers.dino@gmail.com

\section{Author contributions}

Alexandre R. da Silva - formal analysis (equal) and writing original draft (equal). Ana Elisa B. Lopes - conceptualization (equal), writing original draft (equal), investigation (equal). Raphael C. Grabowski - investigation (equal). Antonio L. Castilho - conceptualization (leading), resources (leading), investigation (leading), supervision (leading) and writing-review and editing (leading).

\section{(c) $\mathrm{BY}$}

